\title{
Work-Life Challenges on the Performance of Female Officers in Kenya Police Service, Nakuru County
}

\author{
Margaret Awino Ong'ale ${ }^{1}$, Casper Masiga ${ }^{2}$ \\ ${ }^{1}$ Department of Security and Correction Science, Kenyatta University, Kenya \\ ${ }^{2}$ Department of Sociology, Gender and Development Studies, Kenyatta University, Kenya
}

\begin{abstract}
Police officers play an integral role in enhancing security, which is normally a very basic premise if the economy of a given country is to thrive. The effectiveness and efficiency of police work are doing the right thing to assist the citizens who are their customers at all time. If they don't perform as expected the public can view it with negativity, and term them as either corrupt or unwilling to meet their needs. For a long time, police officers especially female police officers have had numerous challenges that have consistently contributed to their low morale at work thus subsequently having ripple effects on their performance. The purpose of this study was to determine the influence of work-life challenges on the performance offemale police officers in Kenya. The objectives of this study were; to examine the influence of gender stereotypes on the performance of female police officers in Nakuru county; to determine the influence of work-life balance on the performance of female police officers in Nakuru county; to identify how social injustices influences the performance offemale police officers in Nakuru County; and to identify the best strategy to help enhance the performance of female police officers in Nakuru county. The study was guided by radical feminist theory and liberal approach theory. This study also adopted a descriptive survey research design. This study relied on primary data specifically a questionnaire and focus group discussion. A sample of 135 female police officers was drawn through stratified and simple random sampling to respond to the questionnaires. On the other hand, convenience sampling was used to select the female police officers who would participate in the focus group discussion. Descriptive statistics such as mean, percentages and standard deviation were used to analyze quantitative data that was obtained. The data was presented in charts, frequency, and tables. Qualitative data were analyzed according to themes and patterns formed. They were presented in narrative and verbatim quotations forms. This study was expected to contribute to the body of knowledge already existing on challenges facing female police officers and even police officers in general. It was also going to inform the national government on various challenges facing female police officers and how to mitigate them to enhance performance and by extension improving security. The study findings indicated that female officers experienced work-life challenges which included gender stereotypes, work-life balance and social injustices that affected their productivity to some extent. The study concluded that female officers encountered many forms of gender stereotypes at their workplace thus influencing their performance. There was a lot of preference for certain people for promotions or recommendations for promotions that took place at the workplace, a lot of bureaucracy and red tape in the management of police operations and missing certain opportunities for handling certain cases in the force because of their gender. The study also concluded that there was a lack of work-life balance amongst the female police officers as they found it difficult to balance their work and family responsibilities. The study recommends that the government or rather the KPS should come up with policy/policies that will cater for both genders and ensure that there is no favouritism and nepotism in the service as well as adopt practical reforms where possible for female officers to be assigned duties during the day to avoid inconveniences of not being able to attend to family and children.
\end{abstract}

Key Words: Work-Life Challenges, Gender Stereotypes, Work-Life Balance, Social Injustices, 
Female Officers in Kenya Police Service

DOI 10.35942/ ijcab.v5i2.173

\section{Cite this Article:}

Ong'ale, M., \& Masiga, C. (2021). Work-Life Challenges on the Performance of Female Officers in Kenya Police Service, Nakuru County. International Journal of Current Aspects, 5(2), 56-74. https://doi.org/10.35942/ijcab.v5i2.173

\section{Introduction}

Historically, policing was viewed through masculinized lenses, best performed by men. It was largely linked with physical strength, aggressive behaviour and isolation which are all linked to the traditional norms of masculinity and the more reason why policing was a male-dominated profession. A United Nations Women study in 2016 indicated that women only constitute ten percent of police officers globally (UN Women,2016). Though the number was marginal, it reflected the gradual enlistment of women in police institutions globally. This, nonetheless, has had many challenges for the female police officers. According to Garcia (2003), several stages describe the entry of women into policing. Initially, female police officers were given duties that were socially thought to fit the female gender. These duties included child and women protection, women criminals, sex offences and clerical work. Then, women were moved to become the prison and police matrons. However, global police reforms in the 1970s led to more integration of women into the police force. This integration nevertheless did not translate to a change in masculinized attitudes towards policing that led to women being looked down upon. Both policemen and the general public persisted in viewing policewomen as less powerful. The public, therefore, preferred to report to policemen, because of the conception that the policemen were able to solve their problems more than the female officers (Chen,2015).

Policing at the global level is continuously evolving every day. This has seen the enrolment of women in this profession of policing which is different from the early times when the job was only enlisted for men. Research in the U.S. A has proved women face a lot of challenges when they join the police force. This was attributed to the negative attitudes that their male counterparts have towards them. According to Brookshire (1980), the policemen antedate the failing of the female officers; the policemen believed that women cannot equal men regarding the job skills (Bloch and Anderson 1974); the male officers didn't feel like the female officers do the 'real' work of police (Melchionne1976); they got an extent of initiating myths such as, 'women officers were not emotionally fit for the job of policing' (Bell 1982). Horne (1980) argued that the biggest problem that faced female police officers was the negative attitude directed towards them by the male officers. In addition to male officer's negative attitude, women encounter other social challenges that were immanent in broader society and are also common in policing. These include roles and responsibilities in the family, role conflict and roles train (Martin, 1980), capability and self-worth doubts (Glaser and Saxe, 1982), sexual assault (Wong 1984) and assault complain fears (The Council of the City of New York, Committee on Women, 1986).

In Pakistan, there was a significant shortage of women working in law enforcement (ProPakistani, 2017). This was hindered by traditional and cultural gender-oriented obstacles that constrict open community interaction. Sexual assault, corruption, and the lack of equal opportunity have further constricted progress in improving career advancement for policewomen (Seale \& Fulkerson, 2012). In addition, because of the religious beliefs and sociocultural norms, women were always discouraged from joining the police force as it was seen not normal for women and thus taken to be a male domineered profession right from senior to junior officers as well as at planning and policy levels (Individualland,2012). On the contrary, 
the working conditions in the Pakistan police force were male safeguarded of masculine needs and interests. 99\% of total police officers employed in Pakistan were male leaving $1 \%$ for female police officers who were not even in senior positions (Individual land,2012).

In Rwanda, the number of policewomen raised tremendously (Roman,2017). However, they faced different problems such as gender barriers, structural barriers and negative attitude from the policemen. The Rwanda society provided for unequal power relations among women and men, boys and girls hence portrayed a patriarchal social structure. Men were seen to be more superior to women (Balon,2013). Police officers in Tanzania were not satisfied with low salary/ pay, being mistreated by their seniors, poor interpersonal skills, poor housing, poor retirement and pension plans, lack of proper insurance cover and staff training (Magayane, 2008). In Uganda, women police officers stated that they faced a lot of discrimination at the workplace, sexual assault, negative attitude towards them from the public and their colleagues. They also stated that it was hard to balance their family responsibilities and work thus conflict at work with the seniors and low chances of being promoted ( Rabe- Hemp,2011). In Kenya, there has been an increase of policewomen in the service for several years; however, in their line of service at various capacities, they faced challenges that disrupt their productivity in their performance. These challenges were no different from those faced by policewomen globally. In Kenya, among the estimated 101,300 police officers eleven percent are women (Kushner, 2013). The Kenyan constitution also mandated the National Police Service to allow up to thirty percent of the female officers to have raised in their ranks. According to UN Women (2016), the same number of women and men were recruited in Kenya in 2014. Although these numbers are still low, there were pointers to the increased enlistment of policewomen in Kenya. There have also been reforms in the National Police Service which led to a National Act Plan that increased the involvement of female police officers in police work.

\section{Statement of the Problem}

The roles played by female police officers in enforcing the law cannot be overemphasized. For instance, in matters of sexual and gender-based issue cases, people tend to trust women more than their male counterparts. "The females normally trust and engage the female police officers in the investigation of gender-based cases, like rape or gender-based violence; women survivors tend to trust female police officers much more than the male officer who at times humiliate them and cannot understand them. The Kenyan government is trying very much to raise the numbers of policewomen to gives finer services to females who find themselves against the law or are victims in one way or another. The government has even gone an extra mile to reform its entire services and make sure that even female police officers find a better environment to work in, but despite these efforts, there are still several challenges. The few female police officers face numerous work-related problems on service delivery i.e., organizational challenges like life balance between family and work, transfers, proving oneself, intense scrutiny; professional issues such as bullying, sexual assault, and bias. It is from this background that this study researched the work-life challenges on the performance of female officers in Kenya Police Service, Nakuru County.

\section{Purpose of the Study}

i. To examine the influence of gender stereotypes on the performance of female police officers in Nakuru County.

ii. To determine the impact of work-life balance on the performance of female police officers in Nakuru County.

iii. To assess the influence of social injustices on the performance of female police officers 


\author{
in Nakuru County.
}

iv. To identify the best strategy to help enhance the performance of female police officers in Nakuru County.

\title{
4. Theoretical Review
}

\subsection{Radical Feminist Theory}

This is a theory that originated in the USA (Echols \& Willis1990) in the 1970s. Radical feminism, historically, was based on conventions that sexes are always at crossroads. The women were thought to have no power over men. This was the basis for understanding the varying social relationships in the society (Eisenstein1983). Feminists that are radical argue that a system of patriarchal relations derives all types of oppressions (Walby1990). For Marxists, the relationship between capital and labour is majorly influenced by capitalism. In contrast, gender segregation is treated as the fundamental perception by radical feminists. Radical feminists consider the concept of patriarchy as the basis of oppression in employment. Formerly the influence of the father (head of the family) over all his family members was known as patriarchy (Lockwood 1986). Today, the structures and systems that tolerate the power of men over women are referred to as patriarchy (Walby 1990). In its present form, patriarchy is viewed to treat men as privileged and women are seen as a class which breeds inequalities against the women. Radical feminists argued that domestic work as a central obligation is well performed by females in their families and that men are the beneficiaries. Men are given privileges over women in employment because of the gender division of labour that happens to be the root of patriarchal social relation. Radical feminists argue that the lower standing of women economically and socially is enforced by patriarchal aspects. However, some scholars have confronted the notion of patriarchy to explain the modern-day underprivileged standing of females in the workforce. Colgan and Ledwith (1996), for instance, condemn the biological choice of the notion in its traditional form, which insinuates that only males exercise patriarchy. Patriarchy is deep-rooted and point out to male supremacy (Wilson 1995). Similarly, Lockwood (1986) challenges the notion that patriarchy does not apply to contemporary societies due to its reference to particular historical forms of domestic relationships. This is because of the complexities in societal gender segregation in the modern world. In addition to this, other fields of oppression such as race, ethnicity, gender orientation and religion are not explained by patriarchy. This theory was chosen because it broadly explains why women were discriminated against in employment (work-life challenges) in patriarchal societies and the need to provide equal opportunities for both men and women in order to enhance their performance.

\subsection{Liberal Approach Theory}

Liberal approach theory was developed by John Locke in 1689. This theory is grounded on the moral argument that the government's main goal is to ensure that an individual has the right to liberty, life, and property. It is gender-sensitive and advances equity for every person. Attaining the elimination of discriminatory policies and habits in employment is the liberal point of view towards even employment opportunity in organizations. Equal employment conditions and terms of for both genders is what this approach ventures to create. Men and women are viewed equivalent in relation to their current socio-economic ranks and do not recognize any dissimilarities between them by the supporters of the liberal approach theory. Jewson and Mason, (1986) contend that both men and women should have the same employment practices and policies. For example, the working conditions, career growth as well as gender relations in the police service, should be presented equal opportunities for both men and women. Straw defines three levels of impartiality to include "fair chances at the recruitment level, equal access 
to the selection level, and fair shares in the organizational ranking". The liberal proposition focuses on gender neutrality and disdains structural unfairness rooted in culture, traditions and history in the workplace (Jewson and Mason,1986).

In the USA, Australia and other European countries, fair employment opportunity (EEO) practices have been viewed from a liberal approach. The practices emerged in the 1980s and merged the liberal perspectives with capitalist perspectives. Managers were convinced that on the profitability of impartiality for the organizations if the employees were provided a chance to make recruitment, selection and career development decisions based on considerations of the bottom-line (Schwartz 1992). This theory was chosen because it broadly explains the need to offer equal opportunities to both women and men in employment such that failure to do that may translate to work-life challenges for women leading to their low performance.

\section{Conceptual Framework}

Work-life challenges Performance of female police officers

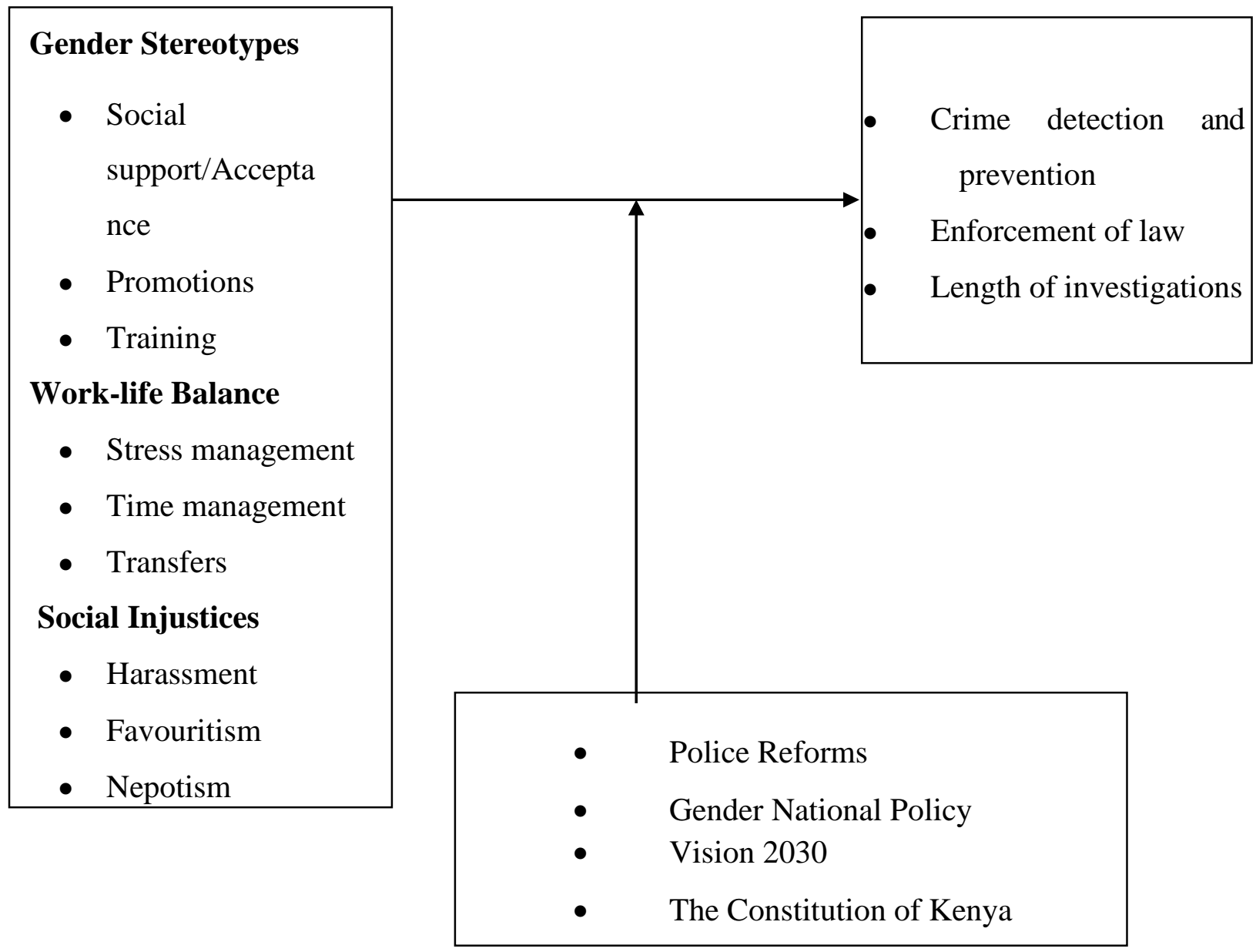

Figure 1: Conceptual Framework

The conceptual framework presents a summary of the interaction between independent and dependent variables. Work-life challenges were the independent variable and it was measured in terms of gender stereotypes (social support/acceptance, training, promotions, and cultural myths), work-life balance (stress management, time management such as flexible working hours, and transfers), and social injustices (sexual harassment, discrimination, favouritism, and nepotism). Depending on the police reforms, which was the intervening variable, they 
determined the performance of policewomen measured in terms of crime spotting and rates of prevention, how well the laws are enforced, and the duration taken into an investigation which is the dependent variable.

\section{Research Methodology}

The study embraced a descriptive survey study method. The design was considered idyllic for the study because it involves collecting data on work-life challenges and police performance without manipulation of the variables. The two data sets were then used to prove the influence of work-life challenges on the performance of policewomen in Nakuru County. This research was conducted in Nakuru County. This study was conducted in 8 police divisions of Nakuru County which comprise Nakuru North, Gilgil, Rongai, Subukia, Molo, Naivasha, Njoro, and Nakuru. The target population was all the 967 female police officers working in all the 70 police stations in Nakuru County. Stratified sampling was used to group the respondents according to the police division they work in. There are 8 police divisions in Nakuru County namely; Nakuru North, Gilgil, Rongai, Subukia, Molo, Naivasha, Njoro, and Nakuru. From an investigation population of 967, a sample specimen was drawn using Nassiuma's formulae (Nassiuma,2000).

The study employed simple random sampling in each stratum to acquire the needed sample size of 135. The study utilized semi-structured questionnaires which contained both open and close-ended questions that were used to get a deeper insight into the research questions. Questionnaires were then taken to the respondents in their respective workplace where the researcher introduced the participants to the intention of the study and obtain their permission to participate in the study. One focus group discussion was carried out with the number of partakers between 6 and 12 female police officers from the eight police divisions. One female police officer was picked from each police division as a focus group discussant through convenience sampling. The discussants were selected by the researcher. The researcher organized appointments with these respondents and carried out the discussions in an area that was suitable to them. The study used both qualitative and quantitative data. Quantitative data were analyzed using descriptive statistics methods such as percentages, frequency, mean and standard deviation. Results were then presented using tables, figures, and charts. Qualitative data were analyzed according to themes, sub-themes, and re-occurring patterns noted from the interviews. They were presented in narrative and verbatim forms.

\section{Research Findings}

\subsection{Gender Stereotypes of Female Officers and Performance}

The first objective of the study was to examine the influence of gender stereotypes on the performance of female police officers in Nakuru County. From the literature reviewed, it was clear that female officers encounter gender stereotypes at their workplace thus influencing their performance. As stated by Uzair (2013), society does not consider the police as a profession of choice for women due to irrational working hours, difficult job environment and the gender stereotyping of police work. According to Susan (1996), despite the growing number of women in policing, women still face barriers which include gender stereotyping of police work. 


\section{Table 1: Gender Stereotypes of Female Officers}

\begin{tabular}{|c|c|c|}
\hline & No & Yes \\
\hline $\begin{array}{l}\text { There are promotions or recommendations for promotions that } \\
\text { take place at my workplace }\end{array}$ & $0.0 \%$ & $100.0 \%$ \\
\hline $\begin{array}{l}\text { In the last } 12 \text { months, I have been promoted from my previous } \\
\text { rank to where I am now. }\end{array}$ & $70.7 \%$ & $29.3 \%$ \\
\hline $\begin{array}{l}\text { Promotions favour only male police officers than female police } \\
\text { officers }\end{array}$ & $42.2 \%$ & $57.8 \%$ \\
\hline $\begin{array}{l}\text { I feel that the government is doing enough to ensure that even } \\
\text { female police officers are promoted in an equal manner as their } \\
\text { male counterparts and their working conditions should be } \\
\text { improved }\end{array}$ & $14.7 \%$ & $85.3 \%$ \\
\hline $\begin{array}{l}\text { There is a lot of bureaucracy and red tape in the management of } \\
\text { police operations }\end{array}$ & $0.0 \%$ & $100.0 \%$ \\
\hline I feel that I have to prove my credibility amongst my peers & $43.1 \%$ & $56.9 \%$ \\
\hline $\begin{array}{l}\text { I have to establish myself due to negative attitudes directed to } \\
\text { female officers }\end{array}$ & $43.1 \%$ & $56.9 \%$ \\
\hline There is good collaboration between units. & $70.7 \%$ & $29.3 \%$ \\
\hline I can trust my partner. & $28.4 \%$ & $71.6 \%$ \\
\hline I view my work as a job it's not a profession & $57.8 \%$ & $42.2 \%$ \\
\hline $\begin{array}{l}\text { There are some trainings that are considered appropriate for male } \\
\text { officers in Policing }\end{array}$ & $14.7 \%$ & $85.3 \%$ \\
\hline $\begin{array}{l}\text { I have missed certain opportunities for handling certain cases in } \\
\text { the force because of my gender }\end{array}$ & $0.0 \%$ & $100.0 \%$ \\
\hline $\begin{array}{l}\text { Negative attitudes towards female officers from their counter } \\
\text { partners and the public affects my performance }\end{array}$ & $57.8 \%$ & $42.2 \%$ \\
\hline $\begin{array}{l}\text { Policing is considered a male-dominated field which makes the } \\
\text { public lose trust in female officers with certain cases }\end{array}$ & $28.4 \%$ & $71.6 \%$ \\
\hline Aggregate Score & $33.7 \%$ & $66.3 \%$ \\
\hline
\end{tabular}

Table 1 above shows the perceptions of the female officers in regards to gender stereotypes and the influence it has on the performance. All the respondents indicated that there were promotions or recommendations for promotions that took place at their workplace, $70.7 \%$ of the respondents indicated that in the last 12 months they had not been promoted from their previous rank to where they were now and $57.8 \%$ of the respondents indicated that promotions favoured only male police officers than female police officers. The findings demonstrated well that policing is still seen as a male affair and thus female officers shut out of opportunities to progress in their career by being denied and discriminated against from getting promotions. They are also looked down upon and certain roles denied to them because of their gender and the belief that certain duties need muscles for them to be carried out. This is just a myth and a way of ruling out the strength of female officers. However, $85.3 \%$ of the respondents felt that the government was doing enough to ensure that even female police officers were promoted in an equal manner as their male counterparts and their working conditions should be improved. Similarly, all the respondents indicated that there was a lot of bureaucracy and red tape in the management of police operations, while $56.9 \%$ of the female officers indicated that they felt that they had to prove their credibility amongst their peers and another $56.9 \%$ indicated they had to establish themselves due to negative attitudes directed to female officers. The study findings are in line with those of Oruta, Lidava and Gaunya (2016) who examined the problems encountered by policewomen and affect their service delivery which included being undermined by their male counterparts, deployment opportunities that are unequal, male 
officers being unresponsive to the needs of policewomen, bullying, not being involved in decision making, sexual harassment, insubordination of senior policewomen and not being considered for promotions when they are due. The study advocated that the organizational management should look at the rules and regulations put in place and ensure that they are followed, consider a female transfer, encourage equality, consider the decisions made by the female police officer, come up with sensitization programs on gender mainstreaming, motivate hardworking female police officers, come up with interdepartmental interaction forums. The findings implied that as much as the government is advocating for a third gender rule the female police officers are not enjoying the benefits of the policy since they do not get promotions to higher posts as the bosses promote their relatives, acquaintances and those affiliated with them. It is quite unfortunate that most women get discriminated against career progression chances because of their gender and many cultural beliefs that policing is for men and not for women hence the ladies being overlooked in carrying out certain duties or holding certain posts simply because they are women and due to the fact that they are seen as weak.

In addition, $70.7 \%$ of the respondents indicated there was no good collaboration between units, while $71.6 \%$ indicated they can trust their partner and $57.8 \%$ indicated they did not view their work as a job it's not a profession. These results agree with those of Morash et al. (2006) who established the capability of women to do what the male counterparts do, such as patrol officers. The only issue that remains is physical strength, which is a topic that is still dominant every other time the female officers are mentioned. The findings implied that gender stereotypes are still being experienced in many government offices and public institutions as much as women are proving to be up to the task in any area that they are posted to work.

Eighty-five point three percent of the respondents indicated there were some trainings that were considered appropriate for male officers in policing while all the respondents indicated that they had missed certain opportunities for handling certain cases in the force because of their gender and $71.6 \%$ indicated that policing was considered a male-dominated field which made the public lose trust in female officers on certain cases. The study findings agree with those of Rabe- Hemp (2009) who found that of 38 female police officers who had an experience of between $10-30$ years to gain a female perspective of police culture, revealed that only 12 of the 38 officers in the study held a rank of corporal or higher. The majority of the officers in the study were junior officers where 20 were deployed as patrolofficersand6 deployed as detectives. Further Burke and Mikkelsen (2004) asserted that female officers are overlooked in carrying out certain duties or holding certain posts simply because they are women and due to the fact that they are seen as weak. For instance; the police examinations sometimes require examination of physical alertness and some are considered gender-based. In several departments, they use a scale of 5 or 6 -foot solid wall in their tests to determine the upper strengthens of individuals. Such measures prevent the women officers from passing the examination seven though they might be strong. Finally, $57.8 \%$ of the respondents indicated that negative attitudes towards female officers from their counter partners and the public did not affect their performance. Results contradict those of Magayane (2008) who opined that police officers in Tanzania are not satisfied with low salary/ pay, being mistreated by their seniors, poor interpersonal skills, poor housing, poor retirement and pension plans, lack of proper insurance cover and staff training. Similarly, Rabe- Hemp (2011) found that in Uganda, women police officers stated that they faced a lot of discrimination at the workplace, sexual assault, negative attitude towards them from the public and their colleagues. They also stated that it was hard to balance their family responsibilities and work thus conflict at work with the seniors and low chances of being promoted. The findings implied that female officers encountered many forms of gender stereotypes at their workplace thus influencing their performance this includes denial in promotions, missing opportunities to handle certain cases in the force, and 
above all the negative perception the public has that policing is a male dominating field.

In regards to gender stereotypes that female officers face during their work, one of the officers from FGD indicated that: -

“...some members of the public think being a woman can hinder you from handling certain cases..."

Another one stated that: -

“...some duties are always performed by a certain gender...".

As for the promotions, the officers indicated that: -

“...there were promotion chances...".

However, in regards to whether there are recommendations for promotions that take place in the workplace; the officers had mixed reactions as some said: - "...promotions should be based on discipline, years of service, gender and tribe while others indicated that recommendations happens sometimes when the opportunities arise...".

The officers from FGDs were further asked to give their opinion on whether the promotions were favouring only policemen than female police officers. The officers said: -

"Yes, the promotions favoured men more than female officers. This was because there is a huge perception of police work as a male affair and they are considered to be more flexible to perform certain duties".

\subsection{Work-life Balance of Female Officers and Performance}

The second objective of the study was to determine the impact of work-life balance on the performance of female police officers in Nakuru County. Policing has a continuous change in work schedules, which lead to unbalanced sleeping patterns (Violanti, 2011). Policing is an involving occupation which is done all round the clock and every day of the year. Sometimes, police officers are asked to extend their work hours, and frequent daily shifts which are incompatible with other non-policing occupations. This creates work-life conflicts and may cause stress and to an extent depression among the officers.

\section{Table 2: Work-life Balance of Female Officers}

\begin{tabular}{lcc}
\hline & No & Yes \\
\hline $\begin{array}{l}\text { I find it tasking to balance work and family responsibilities } \\
\text { I have ways of managing my leisure time }\end{array}$ & $28.4 \%$ & $71.6 \%$ \\
$\begin{array}{l}\text { There are frequent transfers which affect the family life and } \\
\text { children's education }\end{array}$ & $28.4 \%$ & $71.6 \%$ \\
I am given permission by my immediate supervisor to attend to & $13.8 \%$ & $100.0 \%$ \\
family issues periodically & $86.2 \%$ \\
I work for long hours regardless of having children to cater for & $0.0 \%$ & $100.0 \%$ \\
I work at night (nightshift) irrespective of being a mother and a & $14.7 \%$ & $85.3 \%$ \\
wife with family duties to attend to & $100.0 \%$ & $0.0 \%$ \\
Transfers in the Kenya police service are conducted fairly & $85.3 \%$ & $14.7 \%$ \\
I recommend the way transfers are executed. & $100.0 \%$ & $0.0 \%$ \\
Personnel are managed appropriately in the police service & $72.4 \%$ & $27.6 \%$ \\
The workload is realistic for the personnel & $72.4 \%$ & $27.6 \%$ \\
I have a flexible working schedule & $43.1 \%$ & $56.9 \%$ \\
I have ways of managing stress & &
\end{tabular}




\begin{tabular}{lcc}
\hline & No & Yes \\
\hline I usually use my leave days effectively & $27.6 \%$ & $72.4 \%$ \\
I enjoy my maternity leave & $42.2 \%$ & $57.8 \%$ \\
Does Kenya police provide a work-life balance programme for & $100.0 \%$ & $0.0 \%$ \\
officers & $48.6 \%$ & $51.4 \%$ \\
\hline Aggregate Score &
\end{tabular}

Table 2 above reveals that $28.4 \%$ of the respondents indicated that they found it not tasking to balance work and family responsibilities, while another $71.6 \%$ indicated they had ways of managing their leisure time and all of the respondents indicated there were frequent transfers that affected the family life and children's education. Eighty-six point two of the respondents indicated that they were given permission by their immediate supervisor to attend to family issues periodically, all the respondents indicated they worked for long hours regardless of having children to cater for and $85.3 \%$ indicated they worked at night (nightshift) irrespective of being a mother and a wife with family duties to attend to. However, all the respondents disagreed that transfers in the Kenya police service were conducted fairly, $85.3 \%$ disagreed they recommended the way transfers were executed and all of the female officers interviewed disagreed that personnel were managed appropriately in the police service. Kamatchi, Usha and Bhargavi (2013) studied the work-life balance of policewomen of Bangalore and they found that many females were ready to accept the tasking jobs but their work had an effect on their family. They indicated that constantly they had no information they could not carry out their responsibilities in a balanced way. This implies that it was really hard and difficult for the officers to settle well with their families since the transfers are abrupt hence not given enough time to plan and organize for their shifting. This disrupts the family life and tampers with the life of the entire family including the children who have to keep changing from one school to another as the parents keep moving from one area to another. It is also noted that the officers could access permission for emergencies and to handle their family issues which shows a good rapport between the officers and their immediate bosses. However, there was no special treatment to lady officers in regards to night shifts as all had to fit in the duty rosters planned for them whether you have a family, husband and children to attend to.

In addition, $72.4 \%$ of the respondents indicated that the workload was not realistic for the personnel and they did not have a flexible working schedule. Furthermore, $56.9 \%$ of the respondents agreed that they had ways of managing stress, $72.4 \%$ agreed that they usually used their leave days effectively and $57.8 \%$ agreed that they enjoyed their maternity leave. Arguably, all the respondents indicated that Kenya police did not provide a work-life balance programme for officers. Officers remained neutral on the fact that the workload was realistic for the personnel and that there were enough police personnel to police Kenyans. Results are consistent with those of Gachunga and Mumanthi (2014) who established that despite training workers to enhance organization the productivity, work-life balance is also an important factor that stimulates the productivity of the organization. It was pointed out that most of the workers and more specifically the police officers were ailing from work-related illnesses such as stress due to lack of flexible working schedules to address other social issues such as leisure and family issues. The study deduced that there was no control as well as autonomy in the performance of duties and that personnel were not managed appropriately in the police service. The study also inferred that the police officers did not recommend the way transfers were executed that they were not fairly carried out while most of the officers were not satisfied with the way deployment were handled as they were not based on competence in a particular field. The findings implied that many reforms are necessary to be done in the police sector to solve the many challenges officers are facing at the workplace. 
In the focus group discussions, the officers were asked to state whether they have flexible working hours and they stated that: -

“..... single officers have flexible working hours while their married counterparts don't have”.

This was due to the fact that they had to work even at night shifts irrespective of their family responsibilities where they had to take care of their children. The issue of lady officers working at night brought mixed reactions since the married ones had to take care of their families but the single ones could enjoy the night shifts. This issue is a hard one to tackle since even the male officers would also retaliate and say they are married thus the government deems it fit to pass rules and regulations for all officers regardless of their gender and marital status.

On the issue of what the National Police Service could do to help stabilize work and family life for the female officers, the ladies said that: -

"...we think the service should consider family issues in deployment. Lady officers have a family role and can work near the spouse and also a stable transfer policy".

"In my own opinion, this was going to allow officers to plan their working time".

The issue of transfer was raised in that the officers are not given adequate time to relocate inconveniencing the children who have to keep changing schools as they move with their parents. They, therefore, were of opinion that police officers should also have a good work-life balance to enhance their service delivery. This they said because they felt that they are also human and they need to have a social life. One lady officer stated that: -

“...police officers are family humans thus social life is of importance to help integrate into the wider society, and through well managed human resource department" all that can be achieved".

Results are consistent with those of Gachunga and Mumanthi (2014) who established that despite training workers to enhance organization the productivity, work-life balance is also an important factor that stimulates the productivity of the organization. It was pointed out that most of the workers and more specifically the police officers were ailing from work-related illnesses such as stress due to lack of flexible working schedules to address other social issues such as leisure and family issues.

\subsection{Social Injustices of Female Officers and Performance}

The third objective of the study was to assess the influence of social injustices on the performance of female police officers in Nakuru County. Prior studies show that policewomen have witnessed more incidents of social injustices than their male counterparts, and as a result, they have a negative outcome on their mental and physical health, retention, and job commitment. It is factual that female police officers encounter abuse at an alarming rate compared to their male counterparts, and this affects negatively their job contentment, retention, mental health and physical health.

Table 3: Social Injustices of Female Officers

\begin{tabular}{lcc}
\hline & No & Yes \\
\hline There are cases of female sexual harassment at my workplace & $29.3 \%$ & $70.7 \%$ \\
In the last 12 months, there have been cases of sexual harassment & $57.8 \%$ & $42.2 \%$ \\
at my workplace & $71.6 \%$ & $28.4 \%$ \\
I have been sexually harassed at my workplace & $43.1 \%$ & $56.9 \%$ \\
I feel discriminated against at my workplace & $13.8 \%$ & $86.2 \%$ \\
The majority of policewomen feel that the policewomen are the & &
\end{tabular}




\begin{tabular}{lcc}
\hline & No & Yes \\
\hline $\begin{array}{l}\text { ones being sexually assaulted at my workplace } \\
\text { I feel that the female police officers are the ones being sexually }\end{array}$ & $28.4 \%$ & $71.6 \%$ \\
$\begin{array}{l}\text { harassed at my workplace } \\
\text { I feel there is fairness in promotions and rewarding good } \\
\text { performers }\end{array}$ & $100.0 \%$ & $0.0 \%$ \\
$\begin{array}{l}\text { The department tends to be more tolerant in imposing rules and } \\
\text { regulations for policewomen }\end{array}$ & $42.2 \%$ & $57.8 \%$ \\
$\begin{array}{l}\text { Compared to my colleagues (same rank), I find that I am probable } \\
\text { to be more condemned for my mistakes }\end{array}$ & $56.9 \%$ & $43.1 \%$ \\
$\begin{array}{l}\text { I feel that I am less probable to get chosen for various assignments } \\
\text { because of "who I am (e.g., race, gender, sexual orientation, } \\
\text { physical characteristics)" }\end{array}$ & $14.7 \%$ & $85.3 \%$ \\
$\begin{array}{l}\text { Within the department gender-related jokes are often made in my } \\
\text { presence }\end{array}$ & $0.0 \%$ & $100.0 \%$ \\
$\begin{array}{l}\text { Female officers are held to a higher regard than policemen } \\
\text { Police promotion is based on individual performance }\end{array}$ & $70.7 \%$ & $29.3 \%$ \\
$\begin{array}{l}\text { There is a lot of favouritism in the police service } \\
\text { Women are sidelined by men in the line of duty and due to their } \\
\text { tribe }\end{array}$ & $85.3 \%$ & $14.7 \%$ \\
Aggregate Score & $28.4 \%$ & $85.3 \%$ \\
\hline
\end{tabular}

Results on Table 3 above shows that $70.7 \%$ of the respondents agreed that there were cases of female sexual harassment at their workplace, $57.8 \%$ disagreed that in the last 12 months there had been cases of sexual harassment at their workplace and $71.6 \%$ disagreed that they had been sexually harassed at their workplace. Every study that looked at harassment in the police force pointed out that female police officers had witnessed some kind of harassment at some point throughout her profession, for instance, Rabe- Hemp (2007); Cordner and Cordner (2011); Arlether (2016). In furtherance, 56.9\% of the respondents agreed that they felt discriminated at their workplace, while $86.2 \%$ agreed that the majority of policewomen felt that the policewomen were the ones being sexually assaulted at their workplace and $71.6 \%$ agreed that they felt that the female police officers were the ones being sexually harassed at their workplace. The findings are in line with those of Rabe- Hemp (2007) who found out that most of the female police officers experienced some kind of harassment ranging from abuse, discrimination, disrespect at a given time within their profession. Most of the time this abuse was encountered immediately after they were enlisted in the profession.

All the respondents indicated they felt there was no fairness in promotions and rewarding good performers and $58.8 \%$ agreed that the department tends to be more tolerant in imposing rules and regulations for policewomen. Additionally, 56.9\% of the respondents disagreed that compared to their colleagues (same rank), they found that they were probably to be more condemned for their mistakes, while $85.3 \%$ agreed that they felt that they were less probable to get chosen for various assignments because of "who they were (e.g., race, gender, sexual orientation, physical characteristics)" and all the respondents agreed that within the department gender-related jokes were often made in their presence. In addition, Rabe- Hemp (2007) found that females who changed departments experienced sexual abuse, prejudice or disrespect again at their new department. Harassment is therefore seen as an ingredient of stress in female police officers in law enforcement which may occur in various ways such as being touched inappropriately, hearing dirty jokes and stories, to being victimized because they are female. The findings clearly illustrated that female officers suffer in silence as they do not want to be 
judged and at the same time, they do not want to lose their jobs as it was their only means of survival. Stringent measures should be put in place to curb all the social injustices female officers go through in their line of duty, they should also ensure that promotions are conducted in transparency and through merit and not by "who knows who" or the "godfather referral".

Seventy point seven percent of the respondents disagreed that female officers were held to a higher regard than policemen, $85.3 \%$ disagreed that police promotion was based on individual performance while another $85.3 \%$ agreed that there was a lot of favouritism in police service. Finally, $71.6 \%$ of the respondents agreed that women are sidelined by men in the line of duty and due to their tribe. The findings are in support of Brodeur (2018) who found out that women had witnessed quid pro quo harassment, but every woman remembered work-life challenges at some point throughout their profession. Violence against women by men was witnessed more than harassment which was sexual in nature. It was reported by the policewomen officers that even though they participated in gender-related comments/ jokes, they were 'unwanted' hence the jokes are part of the policing culture, and as a result of this, most female officers are targeted due to their gender. Most female officers reported that they could not report the harassment as this could impact negatively on their career growth.

In regards to social injustices faced, the officers expressed that they indeed faced many such as promotion denials, sexual harassments, discrimination. The ladies were vocal that they were denied promotions based on tribal allegations and denied certain duties because are believed to be of a certain gender. The lady officers said that: -

"...I come from one of the large tribes. I have been denied promotion on basis of tribal harshness"

Another one said that: -

"...the unfair allocation of duties to various genders". This demoralizes the officers which can dwindle their performance and wreck their self-esteem".

The cases of sexual harassment were on the rise as all the ladies said to have witnessed it at the workplace whether it has happened to them or their colleagues. They reported that: -

"...I have seen a police officer send romantic messages to a lady officer after a promotional interview" and "I have heard many complains of junior officers complaining against it".

They also said they encountered verbal harassment where the male counterparts discuss their body physique and give unwarranted comments making them uncomfortable. For instance, one female officer stated that: -

“...A male boss made an unwarranted comment on my body physique”.

Women are naturally emotional beings and they get highly irritated if funny comments are made in regards to their body shapes and structure. This eventually makes the officers feel discriminated against at the workplace and makes it difficult working in an office where $90 \%$ of colleagues are male. The discriminations make one feel less appreciated in terms of idea contribution (Rabe- Hemp, 2007)

\subsection{Best Strategies to enhance Performance of Female Police Officers}

The fourth objective sought to identify the best strategies to help enhance the performance of female police officers in Nakuru County. The findings were recorded in Table 4. 
Table 4: Best Strategies to enhance Performance of Female Police Officers

\begin{tabular}{lcc}
\hline Statement & No & Yes \\
\hline Every officer should be rewarded according to their duties & $0.0 \%$ & $100.0 \%$ \\
Every officer should be rewarded according to who they are & $100.0 \%$ & $0.0 \%$ \\
I feel I miss out on posts and promotions because of my gender & $1.8 \%$ & $98.2 \%$ \\
$\begin{array}{l}\text { There are policies that ensure that there is no favouritism in the } \\
\text { service }\end{array}$ & $85.3 \%$ & $14.7 \%$ \\
$\begin{array}{l}\text { There are policies that ensure that there is no nepotism in the } \\
\text { service }\end{array}$ & $98.3 \%$ & $1.7 \%$ \\
$\begin{array}{l}\text { Female police officers are assigned duties during the day to enable } \\
\text { them to attend to their family. }\end{array}$ & $100.0 \%$ & $0.0 \%$ \\
Aggregate Score & $64.2 \%$ & $35.8 \%$ \\
\hline
\end{tabular}

The findings in Table 4 indicate that all respondents felt that every officer should be rewarded according to their duties rather than who they are. There was a $98.2 \%$ indication that the respondents felt that they miss out on posts and promotions due to their gender. Also, 85.3\% of the respondents disagreed that there are policies to ensure that there is no favouritism in the service while $98.3 \%$ disagreed that there are policies that ensure that there is no nepotism in the service. All the respondents disagreed that female police officers are assigned duties during the day to enable them to attend to their family. Moreover, concerning the best strategies, in the focus group discussions, the respondents were asked about what can be done to curb the work-life challenges that female officer's face, the respondents gave different suggestions but the researcher grouped and narrowed them to the following themes. Most of the respondents suggested that: -

“...every officer should be rewarded by their duties and performance and not by who they are". This was seen as a major challenge since they felt that they deserved some of the posts and promotions but they miss them out due to the fact that they are women. It was supported by the responses from the focus group discussion where one of the officers stated that: -

"...there are some duties and roles that are believed for a certain gender, this clearly demoralizes us regardless of the efforts we put in place to progress in our career".

Another suggestion given was that the human resource department should be run by competent personnel. This could help in solving issues and matters relating to employee welfares without compromise and with decorum. As noted from the findings and on focus group discussion the level of disagreement was notably high on the issue of promotions and work-life balance. Most of the officers interviewed stated that: -

"There is a lack of promotional policy regarding promotions and promotion is marred with a lot of patronages and consideration for promotions depends on knowing a senior officer".

An agitated officer complained of being harassed on the board promotion interview. She narrated to the researcher how she was asked questions relating to her marriage and wondered how that was police-related. The respondents interviewed indicated that: -

“...an effective human resource management will improve service delivery and deployment of officers to relevant sections/ departments within the service".

In addition, the respondents indicated that: -

"...the government or rather the KPS should come up with a policy that will cater for both gender and ensure that there is no favouritism, nepotism in the service and adopt practical 
reforms in policing”.

The other subtheme that merged a lot was fair and equal treatment at the workplace. The majority of the officers indicated that: -

"all police officers regardless of who they are should be treated equally and fairly" and "All officers irrespective of gender should be treated equally and with the respect that they deserve at the workplace".

The officers felt that there is a need for all officers, male or female, to be given equal chances and opportunities in handling cases and when promotion vacancies arise. Women should not be discriminated against due to their natural and unique features rather should be embraced to enhance their wellbeing and improve their job performance.

From the FGD, the respondents were asked to state the measures to curb the work-life challenges that they face at their respective workplaces. In their statements, the officers stated that: - "... promotions should be based on merit and not tribe and equal opportunities for men and women should be looked upon."

It also emerged that the Kenya Police Services are highly bureaucratized government institutions, with a clear training curriculum, chain of command, promotion and structure, and effective frameworks. The female officers are meant to be part of this bureaucratic arrangement but they appear to operate in isolation exposing them to the witnessed challenges. The female officers do not enjoy the benefits of the bureaucratic arrangement in equal measure as their male counterparts. Therefore, the best way of implementing the identified measures is to recognize that the female officers are part of the bureaucracy and should be fully incorporated in the organization to progress at the same pace with the rest of the organization without discrimination and favouritism.

\subsection{Performance of Female Police Officers}

The study sought to find out the extent to which the female police officers agreed in relation to statements in regards to performance.

Table 5: Performance of Female Police Officers

\begin{tabular}{|c|c|c|c|c|c|c|c|}
\hline Statement & $\begin{array}{l}\text { Very } \\
\text { poor }\end{array}$ & Poor & $\begin{array}{c}\text { Neithe } \\
\mathbf{r}\end{array}$ & Good & $\begin{array}{l}\text { Very } \\
\text { Good }\end{array}$ & $\begin{array}{c}\text { Mea } \\
\mathbf{n}\end{array}$ & $\begin{array}{c}\text { Std. } \\
\text { Deviati } \\
\text { on }\end{array}$ \\
\hline $\begin{array}{l}\text { Work attendance } \\
\text { (present at place work } \\
\text { and actually working) }\end{array}$ & $3.4 \%$ & $9.5 \%$ & $31.9 \%$ & $33.6 \%$ & $21.6 \%$ & 3.6 & 1.037 \\
\hline Crime detection & $2.6 \%$ & $10.3 \%$ & $14.7 \%$ & $66.4 \%$ & $6.0 \%$ & 3.63 & 0.85 \\
\hline Crime prevention & $0.9 \%$ & $12.1 \%$ & $29.3 \%$ & $41.4 \%$ & $16.4 \%$ & 3.6 & 0.931 \\
\hline $\begin{array}{l}\text { Enforcement of traffic } \\
\text { rules and regulations }\end{array}$ & $0.0 \%$ & $0.0 \%$ & $19.8 \%$ & $26.7 \%$ & $53.4 \%$ & 4.34 & 0.791 \\
\hline Routine security patrols & $2.6 \%$ & $19.8 \%$ & $19.0 \%$ & $48.3 \%$ & $10.3 \%$ & 3.44 & 1.007 \\
\hline $\begin{array}{l}\text { Maintenance of law and } \\
\text { order }\end{array}$ & $1.7 \%$ & $1.7 \%$ & $20.7 \%$ & $44.8 \%$ & $31.0 \%$ & 4.02 & 0.865 \\
\hline $\begin{array}{l}\text { Dealing with } \\
\text { emergencies }\end{array}$ & $0.0 \%$ & $22.4 \%$ & $23.3 \%$ & $31.0 \%$ & $23.3 \%$ & 3.55 & 1.082 \\
\hline Investigating cases & $0.0 \%$ & $3.4 \%$ & $19.8 \%$ & $66.4 \%$ & $10.3 \%$ & 3.84 & 0.645 \\
\hline Taking cases to court & $1.7 \%$ & $6.0 \%$ & $29.3 \%$ & $31.0 \%$ & $31.9 \%$ & 3.85 & 0.998 \\
\hline Prosecuting cases in & $0.0 \%$ & $1.7 \%$ & $33.6 \%$ & $50.9 \%$ & $13.8 \%$ & 3.77 & 0.702 \\
\hline
\end{tabular}




\begin{tabular}{lccccccc}
\hline & $\begin{array}{l}\text { Very } \\
\text { poor }\end{array}$ & Poor & $\begin{array}{c}\text { Neithe } \\
\text { r }\end{array}$ & Good & $\begin{array}{c}\text { Very } \\
\text { Good }\end{array}$ & $\begin{array}{c}\text { Mea } \\
\text { n }\end{array}$ & $\begin{array}{c}\text { Std. } \\
\text { Deviati } \\
\text { on }\end{array}$ \\
\hline $\begin{array}{l}\text { court } \\
\text { Quality of services } \\
\text { provided to the public }\end{array}$ & $0.0 \%$ & $0.9 \%$ & $11.2 \%$ & $50.0 \%$ & $37.9 \%$ & 4.25 & 0.684 \\
$\begin{array}{l}\text { Attending to cases } \\
\text { assigned to you }\end{array}$ & $0.9 \%$ & $2.6 \%$ & $1.7 \%$ & $71.6 \%$ & $23.3 \%$ & 4.14 & 0.645 \\
$\begin{array}{l}\text { Time management and } \\
\text { efficiency }\end{array}$ & $4.3 \%$ & $11.2 \%$ & $19.8 \%$ & $49.1 \%$ & $15.5 \%$ & 3.6 & 1.02 \\
$\begin{array}{l}\text { Analytical competence } \\
\begin{array}{l}\text { Collaborating with local } \\
\text { communities }\end{array}\end{array}$ & $2.6 \%$ & $3.4 \%$ & $20.7 \%$ & $60.3 \%$ & $12.9 \%$ & 3.78 & 0.814 \\
Aggregate Score & $0.0 \%$ & $3.4 \%$ & $13.8 \%$ & $44.0 \%$ & $38.8 \%$ & 4.18 & 0.798 \\
\hline
\end{tabular}

The study findings in Table 5 illustrate that $55.2 \%$ of the respondents indicated that their work attendance (present at place work and actually working) was good, $72.4 \%$ said crime detection was good and $57.8 \%$ indicated crime prevention was good. Additionally, $80.1 \%$ of the respondents revealed enforcement of traffic rules and regulations was good, routine security patrols were rated good by 58.6\%, 75.8\% rated maintenance of law and order as good, 54.3\% indicated dealing with emergencies good. The indicators for performance were all rated good at varying percentages such as investigating cases (76.4\%), taking cases to court $(62.9 \%)$, Prosecuting cases in court (64.7\%), Quality of services provided to the public (87.9\%), Attending to cases assigned to you (94.9\%), Time management and efficiency $(64.6 \%)$, Analytical competence $(73.2 \%)$ and collaborating with local communities $(82.8 \%)$. The aggregate mean score for performance was 3.28 which indicates that the performance was good but still low which could be attributed to the work-life challenges that women face in their duty posts.

\section{Conclusions}

The study concludes that work-life challenges indeed affected the performance of female officers in Nakuru County. The objectives of the study focused on gender stereotypes, worklife balance, social injustices and best strategies and how they affected the performance of female officers. The study concluded that the lady officers encountered many forms of gender stereotypes at their workplace thus influencing their performance. There was a lot of preference for certain people for promotions or recommendations for promotions that took place at the workplace, a lot of bureaucracy and red tape in the management of police operations and missing certain opportunities for handling certain cases in the force because of their gender. The study concludes that there was no work-life balance amongst the officers this was due to the reason that they did not have flexible working time and was hard as well as difficult to handle their family responsibilities. The study further concludes that Kenya police did not have a work-life balance programme for officers, they were asked to extend their work hours, and frequent daily shifts were incompatible with other non-policing occupations. The study findings also showed that officers were not satisfied with the way deployment was done and how transfers were conducted. The officers were of the opinion that they should be given enough time to plan for their relocation since they have families and school-going children thus abrupt transfers disorient their minds. The study concludes that female officers faced social injustices at their workplace which influenced their productivity such as promotion denials, sexual harassments, discrimination. There were cases of jobs assigned to a certain gender since 
they were believed to be more appropriate for the tasks. Promotions were also done inappropriately where names were recommended leaving out the ladies.

\section{Recommendations}

Based on the study findings the following recommendations were made:

i. The government or rather the KPS should come up with a policy that will cater for both genders and ensure that there is no favouritism, nepotism in the service and adopt practical reforms where possible lady officers to be assigned duties during the day to avoid inconveniences of not being able to attend to family and children.

ii. All police officers should be eligible for promotion after training or attaining the required years in the current position, there should be no discrimination and favouritism. Every officer should be rewarded by their duties and performance and not by who they are. Gender equality should be considered for senior position as well as in assigning lucrative assignments to the officers. There should be enjoyment of same privileges for all officers which should be clearly documented in program schedules or policies. Moreover, the working environment and conditions in the KPS should be such that they motivate the officers to deliver quality services.

iii. There should be equal division of working hours among the police officers who are present and available in every police station. The female police officers undertake multiple roles in their families and at work and these dual responsibilities can increase stress levels. Therefore, each police station should ensure it has its own communication channel to allow the female officers to register their demands if any.

iv. The human resource department should be run by competent personnel. This could help in solving issues and matters relating to employee welfares without compromise and with decorum. Effective human resource management will improve service delivery and deployment of officers to relevant sections/ departments within the service. A clear transfer policy should be put in place and a department to handle officers' complaints/related issues should be established.

v. Further, there should be a fair work-life balance programme introduced and implemented to at least cater and address certain issues that the officers are going through and which may affect their productivity.

\section{REFERENCES.}

Angira, Z. (2012). The ghetto life of a Kenyan police officer. Nairobi: Daily Nation.

Aremu,A.O.,\&Adeyoju,C.A.(2003).Jobcommitment,jobsatisfactionandgenderaspredictors of mentoringtheNigeriaPolice.Policing:AnInternationalJournalofPoliceStrategies\& Management,26,377-385.

Burke, R. (2017). Stress in Policing. New York: Routledge

Burke, R., \&Mikkelsen, A. (2004). Gender issues in policing do they matter? Women in Management Review, 20, 133-143.

Carlan PE. (2007). The search for job satisfaction: a survey of Alabama policing. AmJ Crime Justice.; 32(1-2), 74-86.

Chen, R. (2015). Women in Policing: In relation to female police officers' level of motivation toward the career, level of stress, and attitude of misconduct.Sociological Imagination: Western's Undergraduate Sociology Student Journal, 4(1),1-18.

Colgan, F. and Ledwith, S. 1996. Women as organisational change agents, in Ledwith, S. and Colgan, F. (Eds), Women in Organisations: Challenging Gender Politics, London: Macmillan Business 
Creswell, J.W., (2014). Research Design: Qualitative, Quantitative, and Mixed Methods Approaches (4th Ed.) Thousand Oaks, CA: Sage.

Dorius, F. Shawn. (2010).Trends in Global Gender Inequity. Journal of Social Force,88(5),1941- 1968.

Eisenstein H. (1983). Contemporary Feminist Thought, Boston: G. K. Hall \& Co.

Falken L. E \&Bol and L. (2012). Eliminating the Barriers to Employment equity in the Canadian Workplace. Journal of Barriers Ethics, 16(9),963975.

Garcia, V. (2003). "Difference" in the Police Department Women, Policing, and "Doing Gender".Journal of Contemporary Criminal Justice, 19(3), 330-344.

He, N., Zhao, J., \& Archbold, C. A.(2002).Gender and police stress: The convergent and divergent impact of work environment, work-family conflict, and stress coping mechanisms of female and male police officers. Policing: An International Journal of Police Strategies \& Management, 25(4),687-708.

Individualland. (2012). Research Report on Male Police Perception about Female Police in Pakistan.

Jewson,N.andMason,D.1986.TheTheoryandPracticeofEqualOpportunitiesPolicies:Liberal and Radical Approaches, Sociological Review,34(2).

Kushner, J. (2013, 11 14). Kenya: A high-ranking female police officer shares her view from the top. GlobalPost. Kenya: Publication Radio International.

Lockwood, D. 1986, Class, status and gender, in Crompton, R. and Mann, M. (Eds), Gender and Stratification, London: Polity Press.

Maxwell, J. A (2013).Qualitative research design: An interactive approach(3 ${ }^{\text {rd }}$ ed.) (Sage Applied Social Research Methods Series, Vol. 41).Thousand Oaks, CA: Sage

Morash M, Haarr R, Kwak D-H (2006). Multilevel influences on police stress. AMJ Contemp Crime Justice, 22(1), 26-43.

Mugenda, O.M., \&Mugenda. A.G. (2007). Research Methods, Qualitative and Quantitative Approaches. Nairobi: African Centre for Technology Studies Press, Nairobi

Nassiuma, D.K. (2000). Survey Sampling; Theory and Methods. Nairobi: Nairobi University.Press.

National Bureau of Statistics. (2017). Gender Analysis: Summary of the Number of Police officers and the ratio compared to civilians per County. Kenya National Bureau of Statistics.

Nilsson, M., Griggs, D., \&Visbeck, M. (20162)6. Map the interactions between sustainable development goals: A simple way of rating relationships between the targets to highlight priorities for integrated policy. Nature, 534(7607), 320-323.

Oruta, E., Lidava, M.,\& Gaunya, C. (2016). Challenges facing female police officers in service delivery in Kenya. Journal of Resources Development and Management, 25,1-10.

ProPakistani. (2017). Sindh Govt Increases Quota for Women in Police from 2\% to 5\%.ProPakistani. Sindh: ProPakistani.

Roman, R. (2017). Increase in Female Police Officers in Africa Positively Impacts Peace Processes. The Epoch Times. Africa: Epoch Times.

Schwartz, F.N.and Zimmerman,J. (1992_.BreakingwithTradition: Women and Work, the New Facts of Life, New York: WarnerBooks.

Sommer, B. \& R (2007). A practice guide to behaviour research and technique tools; (4th Ed.): York police science and management vol. 11. No 3 Studies vol 2, no 1.

Thompson S.K., (2002). Sampling, 3rd Edition; Survey Research Methods \& Sampling: Wiley Authenticity Guarantee Publishers.

UN Women. (2016). Women Police Climb the ranks across Africa. Nairobi: UN. Walby, S. 1990. Theorising Patriarchy, Oxford: Blackwell Publishing. 


\section{[IJCAB}

Watson, S.D. 1994. Applying theory to practice: a prospective and prescriptive analysis of the implementation of the Americans with disabilities act, Journal of Disability Policy Studies, 5: 1-24.

Woolsey, Shannon. (2010). Challenges for Women in Policing. Hendon Publishing Company This is an open-access article published and distributed under the terms and conditions of the (c) (i) (s)

Creative Commons Attribution 4.0 International License of United States unless otherwise stated. Access, citation and distribution of this article is allowed with full recognition of the authors and the source. Authors seeking to publish with an Internationally Peer Reviewed Journals should consider https://www.ijcab.org/ by writing to the Editor at editor@ijcab.org or submitting online at https://journals.ijcab.org/journals/index.php. The articles must be quality and meet originality test.

$\frac{\text { IJCAB }}{\text { Publishing Group }}$ 